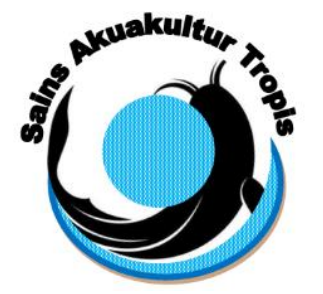

\author{
Jurnal Sains Akuakultur Tropis \\ Departemen Akuakultur \\ Fakultas Perikanan dan IImu Kelautan - Universitas Diponegoro \\ JI. Prof. Soedarto, SH, Tembalang, Semarang 50275 \\ Telp. (024) 7474698, Fax.: (024) 7474698 \\ Email: sainsakuakulturtropis@gmail.com, sainsakuakulturtropis@undip.ac.id
}

\title{
PENGARUH PEMBERIAN PAKAN ALAMI Moina sp. DENGAN DOSIS YANG BERBEDA DALAM Feeding Regime TERHADAP PERTUMBUHAN DAN KELULUSHIDUPAN LARVA IKAN BAUNG (Hemibagrus nemurus)
}

\author{
The Effect of Live Feed Moina sp. with Different Dosage in the Feeding regime to Growth and Survival Rate of \\ Baung (
}

\section{Anggi Trisna Dewi, Suminto*), Ristiawan Agung Nugroho}

Departemen Akuakultur,

Fakultas Perikanan dan Ilmu Kelautan,

Jl. Prof. Soedarto, SH, Tembalang, Semarang, Jawa Tengah -50275, Telp/Fax. +62247474698

* Corresponding author: suminto57@gmail.com

\begin{abstract}
ABSTRAK
Ikan baung (Hemibagrus nemurus) merupakan salah satu ikan endogeneous air tawar yang memiliki harga jual yang tinggi dan memiliki nilai ekspor. Ikan baung masih sangat jarang dibudidayakan dan hanya mengandalkan hasil tangkapan, sehingga perlu dilakukan usaha budidaya. Pakan alami harus diberikan dengan jumlah yang sesuai karena ikan akan tumbuh tidak maksimal apabila pakan yang diberikan terlalu sedikit ataupun terlalu banyak. Moina sp. merupakan salah satu pakan alami yang dapat diberikan pada larva ikan baung. Moina sp. memiliki kandungan gizi yang terdiri dari protein 37,38\%, lemak 13,29\%, serat kasar 0,00\%, abu 11,00\%, dan kadar air sebesar 99,60\%. Ukuran Moina sp. berkisar 500-1.000 $\mu \mathrm{m}$ yang sangat cocok digunakan sebagai pakan awal larva ikan. Penelitian ini bertujuan untuk mengevaluasi pengaruh pemberian pakan alami Moina sp. dengan dosis yang berbeda dalam feeding regime terhadap pertumbuhan dan kelulushidupan larva ikan baung serta mengetahui dosis terbaik Moina sp. terhadap pertumbuhan dan kelulushidupan larva ikan baung. Penelitian dilaksanakan di Unit Pelaksana Teknis Balai Benih Ikan (UPT BBI) Sawangan, Kabupaten Magelang pada bulan Maret-Mei 2018. Ikan uji yang digunakan adalah larva ikan baung D3 dengan panjang $0.6 \pm 0,1 \mathrm{~cm}$. Penelitian ini menggunakan metode eksperimen dan rancangan acak lengkap (RAL) terdiri atas 4 perlakuan dan 3 kali ulangan. Perlakuan yang diterapkan adalah perlakuan A 5ind/ml, B $10 \mathrm{ind} / \mathrm{ml}$, C $15 \mathrm{ind} / \mathrm{ml}$, dan D $20 \mathrm{ind} / \mathrm{ml}$. Hasil penelitian menunjukkan bahwa dosis pakan alami Moina sp. berpengaruh sangat nyata $(\mathrm{P}<0,01)$ terhadap TKP, Pm, SGR, EPP, PER dan RGR namun tidak berpengaruh nyata $(\mathrm{P}>0,05)$ terhadap SR. perlakuan D memberikan nilai panjang mutlak, SGR dan SR terbaik pada D3-D15 yaitu berturut-turut $0.9 \pm 0.10,7.04 \pm 0.51,90 \pm 3.33$. Pada D16-D28 panjang mutlak, SGR, FCR, EPP, PER, RGR dan SR berturut-turut $0.8 \pm 0.10,3.55 \pm 0.17,1.31 \pm$ $0.1,76.76 \pm 6.2,1.53 \pm 0.1,5.24 \pm 0.5,85.22 \pm 3.5$.
\end{abstract}

Kata kunci : ikan baung; pakan alami; Moina sp; pertumbuhan,; kelulushidupan.

\section{ABSTRACT}

Baung (Hemibagrus nemurus) is one of the endogeneous freshwater fish that has economic value. Baung still rarely cultivated and only relies on catches, so its need to be cultivated. Live feed must be given the appropriate amount because the fish will grow not optimally if the feed is a few or too much. Moina sp. is one of the live feeds that can be given to baung larvae. The nutritions content of Moina sp. were 37.38\% protein, $13.29 \%$ fat, $0.00 \%$ crude fiber, $11.00 \%$ ash, and $99.60 \%$ moisture content. Size of Moina sp. that suitable for larvae ranges is $500-1,000 \mu \mathrm{m}$. The aim of this study was to evaluate the effect of live feed Moina sp. with different doses in feeding regime on growth and survival of larvae baung and to determine the best dose of Moina sp. on growth and survival larvae baung. The research was carried out at the Technical Implementation Unit of the Fish Larvae Center (UPT BBI) Sawangan, Magelang District in March-May 2018. The individuals of D3 larvae with a length of $0.6 \pm 0.1 \mathrm{~cm}$ were used in the culture. The research was conducted using experimental method with completely randomized design (CRD) with 4 treatments and 3 replicates. Those treatments were treatment A (5ind / ml), B $(10 \mathrm{ind} / \mathrm{ml}), C(15 \mathrm{ind} / \mathrm{ml})$, and $\mathrm{D}(20 \mathrm{ind} / \mathrm{ml})$. The results showed that the different dose of live feed Moina $\mathrm{sp}$. significantly affected $(P<0.01)$ on TKP, Pm, SGR, EPP, PER and RGR but not significantly affected $(P>0.05)$ 
on SR. in. treatment D showed the best value of absolute length, SGR and SR in D3D15 stage were 0.9 \pm 0.10 , $7.04 \pm 0.5,90 \pm 3.3$, respectivel. In other addition of D15-D28 had absolute length, SGR, FCR, Feed utilization efficiency, PER, RGR and SR were 0.8 $\pm 0.10, S G R 3.55 \pm 0.17,1.31 \pm 0.1,76.76 \pm 6.2,1.53 \pm 0.1,5.24 \pm 0.5$, $85.22 \pm 3.5$. However, $20 \mathrm{ind} / \mathrm{ml}$ of Moina sp dosage which be recommend for baung larval rearing in hatchery.

Keywords: baung, live feed, Moina sp., growth, survival rate.

Article Received: 21-07-2018; Accepted: 21-01-2019

\section{PENDAHULUAN}

Ikan Baung merupakan salah satu ikan endogeneous yang dapat ditemukan di Indonesia. Ikan endogeneous merupakan ikan yang hidup pada habitat yang spesifik dan sangat peka terhadap perubahan lingkungan di sekitarnya. Menurut Muflikhah et al.(2006), Ikan baung yang berasal dari daerah aliran Sungai di Sumatera, Kalimantan, dan Jawa memiliki prospek pengembangan yang cukup bai, selain keunggulan pada sifatsifat biologi seperti memiliki ukuran yang cukup besar, fekunditas yang cukup tinggi, Memiliki nilai ekonomi yang penting karena nilai jual cukup tinggi, saat ini harga di pasaran Kota Palembang berkisar Rp.20.000,- per kg dalam bentuk ikan segar, dan menjadi lebih tinggi lagi dalam bentuk ikan asapan (salai) dengan harga Rp.100.000,per kg. Ikan baung masih sangat jarang dibudidayakan dan hanya mengandalkan hasil tangkapan, sehingga perlu untuk dilakukannya usaha budidaya.

Kegiatan budidaya perlu ditunjang dengan pengembangan usaha pembenihan ikan, usaha ini diharapkan mampu menyediaan benih yang memadai dan berkualitas. Menurut Huwoyono et al. (2011), permasalahan yang terkait dengan pengembangan usaha pembenihan dan pembesaran ikan baung pada skala lapang yaitu benih masih mengandalkan hasil tangkapan alam. Pengembangan budidaya dan usaha pelestarian ikan baung dapat terlaksana apabila benih bermutu baik, tersedia, pakan yang tepat, pencegahan penyakit serta lingkungan hidup yang baik untuk mendukung kehidupan dan pertumbuhannya.

Pakan merupakan salah satu faktor yang dapat mempengaruhi pertumbuhan dan kelangsungan hidup ikan. Pakan alami harus diberikan dengan jumlah yang sesuai karena ikan akan tumbuh tidak maksimal apabila pakan yang diberikan terlalu sedikit ataupun terlalu banyak. Menurut Yustina (2003) kematian larva yang tinggi disebabkan larva sudah kehabisan cadangan makanan berupa kuning telur, sedangkan pakan alami yang tedapat didalam media hidupnya tidak sesuai dengan kebutuhan serta makanan tidak sesuai dengan jenis, ukuran dan jumlah.

Moina sp. merupakan salah satu pakan alami yang baik untuk diberikan pada larva ikan baung karena ukuran yang sesuai dengan bukaan mulut larva baung yaitu pada hari ke 3 antara $0.8-1.00 \mathrm{~mm}$, pergerakannya yang aktif dapat menarik perhatian larva. Menurut Rottmann et al (2003), Cladocera merupakan kelompok udangudangan kecil atau biasa disebut dengan water fleas (kutu air). Sebutan kutu air karena ukuran kecil berkisar 0,9$1,8 \mathrm{~mm}$ dan melayang tersentak di dalam air sehingga sangat cocok digunakan sebagai pakan awal larva ikan karena ukurannya sesuai dengan bukaan mulut larva ikan. Pemberian pakan yang tidak sesuai dengan bukaan mulut larva akan mengakibatkan larva tidak mampu mengkonsumsi pakan tersebut. Pakan alami yang tidak termanfaatkan dapat menyebabkan kualitas air media menurun, sehingga dalam pemberian pakan alami jumlah pakan alami yang diberikan harus sesuai agar dapat dimanfaatkan.

Penelitian mengenai pemakaian Moina sp. sebagai pakan awal pada larva ikan telah banyak dilakukan dalam beberapa penelitian diantaranya pada penelitian Hung et al (2002) yang menggunakan Moina sp untuk pakan awal untuk ikan patin (Pangasius bocourti). Lalu Rahmah et al (2014) yang menggunakan Moina sp sebagai pakan alami dalam penelitian pengaruh photoperiod larva ikan baung dan Srichanun et al, (2012), juga telah melakukan penelitian mengenai aktivitas enzim pencernaan pada ikan baung yang diberi pakan Moina sp namun belum ditentukan jumlah pakan alami Moina sp terbaik untuk pertumbuhan larva ikan baung.sehingga penelitian ini diharapkan mampu memberikan informasi dosis terbaik yang dapat diberikan pada ikan baung untuk menunjang pertumbuhan dan kelulushidupannya.

\section{MATERI DAN METODE}

Prosedur dalam penelitian ini terdiri dari persiapan dan tahap pelaksanaan. Tahap persiapan penelitian meliputi persiapan wadah, kultur pakan pakan alami, dan pemijahan ikan baung. Persiapan hewan uji dilakukan dengan menyeleksi ikan yang sehat dan mempunyai ukuran yang seragam. Persiapan yang dilakukan pada wadah kultur pakan alami adalah pencucian dan penjemuran wadah agar terhindar dari kontaminasi dan wadah untuk pemeliharaan larva ikan baung meliputi pembersihan, pengeringan wadah dan pemasangan alat seperti aerator, selang dan batu aerasi pada setiap wadah perlakuan. Setelah ember pemeliharaan larva baung siap maka dilakukan penebaran larva baung dengan kepadatan 5 ekor/L. Kultur Moina sp. dilakukan dengan cara mencuci bersih terlebih dahulu wadah kultur kemudian diberi aerator. Wadah diisi air dengan volume air 250 liter kemudian ditambahkan pupuk kandang yang telah difermentasi selama 1 minggu lalu ditunggu hingga 1 minggu. Setelah 1 minggu maka bibit Moina sp.yang telah diambil dari hasil kultur balai ditebar dan akan tumbuh setalah 7-8 hari. Kualitas air dijaga dengan pH 7-8 dan kadar DO minimal 3,5 mg/l. Kultur chlorella dilakukan dengan cara bibit 
Chlorella vulgaris $1 \mathrm{~L}$ terlebih dulu dikultur bertahap pada wadah $10 \mathrm{~L}$ selama 7 hari dengan cara mensterilisasi wadah toples bervolume $10 \mathrm{~L}$ dengan menggunakan air yang telah diberi Chlorin 20 ppm sebanyak $10 \mathrm{ml}$ dan di diamkan selama 24 jam.setelah 24 jam air tersebut di buang dan wadah dibersihkan dengan alcohol $70 \%$. Setelah wadah kering lalu dimasukan air laut sebanyak $10 \mathrm{~L}$ yang sudah disterilisasi sebelumnya menggunakan Chlorin 20 ppm sebanyak $10 \mathrm{ml}$ selama 24 jam. Setelah air laut dimasukan kedalam wadah toples maka diberi Natrium tiosulfat sebanyak $10 \mathrm{ml}$ kemudian di aerasi keras selama 10 menit. Setelah itu baru dimasukan pupuk walne dan vitamin b12 serta bibit Chlorella vulgaris. Media pemeliharaan diberi cahaya lampu agar tumbuh dengan baik. Setelah 7 hari maka bibit Chlorella vulgaris siap untuk ditebar ke wadah pemeliharaan bervolume $1000 \mathrm{~L}$ menggunakan air tawar. Pada kultur massal yang perlu dilakukan adalah mensterilkan wadah pemeliharaan menggunak Chlorin 20 ppm sebanyak 1 L dibiarrkan selama 24 jam. Setelah itu ditambahkan Natrium tiosulfat sebanyak $1 \mathrm{~L}$ dan diaerasi kencang selama 3 jam untuk menghilangkan Chlorin pada media kultur. Setelah itu maka dapat dimasukan pupuk seperti KCL dengan dosis $0.2 \mathrm{~g} / \mathrm{l}, \mathrm{NPK}$ 0,1 g/l, ZA 0,8 g/l, Kapur $0.01 \mathrm{~g} / \mathrm{l}$, dan urea $0,1 \mathrm{~g} / \mathrm{l}$. setelah semua pupuk masuk maka bibit Chlorella vulgaris dapat ditebar.

Penelitian ini dilaksanakan selama 28 hari. Penelitian ini menggunakan ikan baung umur 3 hari. Pemberian pakan alami diberikan dengan frekuensi 3 kali sehari pada pagi,siang dan sore hari. Pemberian pakan Moina sp. dilakukan pada umur 3 (D3). Pakan yang diberikan sesuai dengan perlakuan yang telah ditetapkan yaitu perlakuan A sebanyak $5 \mathrm{ind} / \mathrm{ml}$, Perlakuan B $10 \mathrm{ind} / \mathrm{ml}$, perlakuan C $15 \mathrm{ind} / \mathrm{ml}$, perlakuan D $20 \mathrm{ind} / \mathrm{ml}$. Pemberian Moina sp. dilakukan mulai dari D3 sampai D15 dan pada hari ke 14 larva mulai diberi pakan buatan fengli 0 namun masih diberi pakan alami Moina sp dengan jumlah yang lebih sedikit.pada hari ke 15 larva sudah diberi pakan fengli 0 saja secara fix feeding rate sebanyak 5\% dari biomassa ikan. Sampling kelulushidupan dilakukan pada awal pemeliharaan dan akhir pemeliharaan dengan cara menghitung larva yang hidup sedangkan pertumbuhan nya di sampling tiap minggu dengan mengambil data panjang. Kualitas air diukur setiap pukul 07.00, 12.00 dan 16.00 setiap hari. Feeding regime ikan baung dalam penelitian dapat dilihat pada Gambar 1.

\begin{tabular}{|c|c|c|c|c|c|c|c|}
\hline & & & & \multicolumn{4}{|c|}{ Pakan Buatan fengli $05 \%$ bobot biomassa } \\
\hline & \multicolumn{5}{|c|}{ Moina $\mathrm{sp} 5 \mathrm{ind} / \mathrm{ml}$} & & \\
\hline & \multicolumn{5}{|c|}{ Moina sp $10 \mathrm{ind} / \mathrm{ml}$} & & \\
\hline & \multicolumn{5}{|c|}{ Moina sp $15 \mathrm{ind} / \mathrm{ml}$} & & \\
\hline & \multicolumn{5}{|c|}{ Moina $\mathrm{sp} 20 \mathrm{ind} / \mathrm{ml}$} & & \\
\hline \multicolumn{6}{|c|}{ Chlorella $5.10^{5}(\mathrm{sell} / \mathrm{ml})$} & & \\
\hline D1 & D3 & D7 & D13 & D14 & D15 & D21 & D28 \\
\hline
\end{tabular}

Gambar 3. Feeding regime ikan baung

Rancangan percobaan yang digunakan dalam penelitian ini adalah Rancangan Acak Lengkap (RAL) dengan 4 perlakuan dan 3 pengulangan yang mengacu pada penelitian Sichanun et al (2012). Adapun perlakuan penelitian ini adalah

Perlakuan A : pakan alami dosis $5 \mathrm{ind} / \mathrm{ml}$

Perlakuan B : pakan alami dosis $10 \mathrm{ind} / \mathrm{ml}$

Perlakuan $\mathrm{C}$ : pakan alami dosis $15 \mathrm{ind} / \mathrm{ml}$

Perlakuan D : pakan alami dosis $20 \mathrm{ind} / \mathrm{ml}$

\section{Pengumpulan dan perhitungan data}

Pengumpulan dan perhitungan data yang dilakukan dalam penelitian ini dibagi menjadi 2 dimana pada D3 sampai D15 yaitu TKP pakan alami, Panjang mutlak, SGR, SR dan D16 sampai D28 meliputi data TKP pakan buatan, FCR, EPP, PER dan RGR, Panjang mutlak, SGR dan data yang diambil pada awal dan akhir penelitian adalah Panjang mutlak, SGR dan SR.

- Tingkat konsumsi pakan : TKP = F1 - F 2, dimana TKP : Total konsumsi pakan, F1 : Stok pakan yang akan diberikan selama penelitian (g), F2 : Stok pakan yang tersisa dari penggunaan selama penelitian (g).

- Panjang mutlak: $\mathrm{Pm}=\mathrm{Lt}-\mathrm{Lo}$, dimana $\mathrm{L}=$ Pertumbuhan panjang mutlak $(\mathrm{cm}), \mathrm{t}=$ waktu yang dihabiskan untuk penelitian (day), o = awal penelitian (day)

- Laju Pertumbuhan spesifik: SGR $=(\operatorname{logLt}-\log$ Lo/t), dimana_G : Laju pertumbuhan spesifik $(g)$, Lt : panjang ikan pada akhir pemeliharaan $(\mathrm{cm})$, L0 : panjang ikan pada awal pemeliharaan $(\mathrm{cm}), \mathrm{t}$ : lama pemeliharaan (day) 
- Efisiensi Pemanfaatan pakan: EPP = (Wt - W0 / F) x 100\%, dimana EPP : Efisiensi pemanfaatan pakan (\%), Wt : Bobot total ikan uji pada akhir penelitian (g) W0 :Bobot total ikan uji pada awal penelitian (g), F : Jumlah pakan yang dikonsumsi selama penelitian $(\mathrm{g})$.

- Protein efisiensi Ratio: PER = (Wt - W0 / Pi) x 100\%, dimana PER : Rasio efisiensi protein (\%), Wt : Bobot total ikan uji pada akhir penelitian (g) W0 :Bobot total ikan uji pada awal penelitian (g), Pi : Berat pakan yang di konsumsi x \% protein pakan.

- Laju pertumbuhan relative : $\mathrm{RGR}=(\mathrm{Wt}-\mathrm{W} 0 / \mathrm{W} 0 \times \mathrm{t}) \times 100 \%$, dimana RGR : Laju pertumbuhan ralatif (\%), Wt : Bobot total ikan uji pada akhir penelitian (g) W0 :Bobot total ikan uji pada awal penelitian (g), $\mathrm{t}$ : waktu pemeliharaan (hari).

- Survival Rate: $\mathrm{SR}=(\mathrm{Nt} / \mathrm{N} 0)$ x 100\%, dimana SR : tingkat kelulushidupan ikan (\%), $\mathrm{N}_{\mathrm{t}}$ : Jumlah ikan pada akhir penelitian (ekor), $\mathrm{N}_{0}$ : Jumlah ikan pada awal penelitian (ekor).

\section{Analisis Data}

Analisis data terhadap feeding regime larva ikan baung dibagi menjadi 2 fase untuk kemudahan analisis yaitu pada D3-D15 dan D15-D28. Pada fase D3-D15 data yang diambil yaitu Tingkat konsumsi pakan (TKP) alami, Panjang mutlak (Pm), Laju pertumbuhan spesifik (SGR) dan Survival Rate (SR). Pada D15- D28 data yang dianalisis meliputi total konsumsi pakan (TKP) buatan, Panjang mutlak (Pm), Laju pertumbuhan spesifik (SGR), efisiensi pemanfaatan pakan (EPP), protein efisiensi rasio (PER), rasio konversi pakan (FCR), laju pertumbuhan relatif (RGR) dan kelulushidupan (SR) yang didapatkan kemudian dianalisis dengan menggunakan analisis sidik ragam (ANOVA) pada taraf kepercayaan $95 \%$ dan $99 \%$ untuk melihat pengaruh perlakuan. Apabila dalam analisis ragam diperoleh berpengaruh nyata $(\mathrm{P}<0,05)$ atau berpengaruh sangat nyata $(\mathrm{P}<0,01)$, maka dilakukan uji wilayah ganda duncan untuk mengetahui perbedaan antar perlakuan. Data dibagi menjadi 2 fase agar dapat membandingkan dan mengkaitkan performa pertumbuhan dan kelulushidupan larva ikan baung ketika diberi pakan alami dan saat diberi pakan buatan. Data kualitas air dianalisis secara deskriptif dan dibandingkan dengan nilai kelayakan kualitas air untuk mendukung pertumbuhan ikan.

\section{HASIL}

\section{a. Performa pertumbuhan D3-D15}

Berdasarkan hasil pemeliharaan D3-D15 didapat data pertumbuhan panjang mutlak $\left(\mathrm{P}_{\mathrm{m}}\right)$, laju pertumbuhan spesifik (SGR) yang dapat dilihat pada Tabel 1.

Tabel 1 Nilai Rerata Pm, SGR (Hemibagrus nemurus) selama Penelitian

\begin{tabular}{ccccc}
\hline \multirow{3}{*}{ Perlakuan } & \multicolumn{4}{c}{ Parameter } \\
\cline { 2 - 5 } & $\begin{array}{c}\text { TKP pakan } \\
\text { alami (ind/ml) }\end{array}$ & $\begin{array}{c}\text { Panjang Mutlak } \\
(\mathrm{cm})\end{array}$ & SGR (\%/hari) ( \pm SD) & SR (\%) \\
\hline A & $52 \pm 1.53^{\mathrm{d}}$ & $0.40 \pm 0.10^{\mathrm{b}}$ & $3.90 \pm 0.77^{\mathrm{b}}$ & $86.67 \pm 2.72^{\mathrm{a}}$ \\
B & $101 \pm .1 .0^{\mathrm{a}}$ & $0.57 \pm 0.15^{\mathrm{b}}$ & $5.07 \pm 1.03^{\mathrm{b}}$ & $86.67 \pm 3.33^{\mathrm{a}}$ \\
C & $155 \pm 1.0^{\mathrm{b}}$ & $0.80 \pm 0.10^{\mathrm{a}}$ & $6.50 \pm 0.55^{\mathrm{a}}$ & $88.89 \pm 5.09^{\mathrm{a}}$ \\
D & $176 \pm 4.58^{\mathrm{a}}$ & $0.90 \pm 0.10^{\mathrm{a}}$ & $7.04 \pm 0.51^{\mathrm{a}}$ & $90.00 \pm 3.33^{\mathrm{a}}$ \\
\hline
\end{tabular}

Keterangan :

Nilai rerata dengan huruf superscript yang berbeda menunjukkan adanya perbedaan sangat nyata $(\mathrm{P}<0,01)$.

Berdasarkan Tabel 1. rata-rata TKP pakan alami pada masing-masing perlakuan dari yang tertinggi hingga yang terendah adalah perlakuan D sebesar 176 \pm 4.58 , perlakuan C sebesar $155 \pm 1.0$, perlakuan B sebesar 101 \pm .1 .0$ dan perlakuan A sebesar 52 \pm 1.53. rata-rata panjang mutlak $(\mathrm{Pm})$ pada masing-masing perlakuan dari yang tertinggi hingga yang terendah adalah perlakuan D sebesar $0.90 \pm 0.10$, perlakuan C sebesar $0.80 \pm 0.10$, perlakuan B sebesar $0.57 \pm 0.15$, dan perlakuan A sebesar $0.40 \pm 0.10$. Rata-rata nilai laju pertumbuhan spesifik (SGR) pada masingmasing perlakuan dari yang tertinggi hingga yang terendah adalah perlakuan D sebesar 7.04 \pm 0.51 , perlakuan C

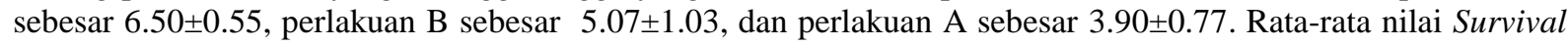
Rate (SR) pada masing-masing perlakuan dari yang tertinggi hingga yang terendah adalah perlakuan D sebesar $90.00 \pm 3.33$, perlakuan C sebesar $88.89 \pm 5.09$, perlakuan B sebesar 86.67 \pm 3.33 , dan perlakuan A sebesar $86.67 \pm 3.33$.

Berdasarkan data nilai Panjang mutlak dan SGR pada ikan baung selama pemeliharaan D3-D15 maka dapat dibuat grafik pada Gambar 1. 

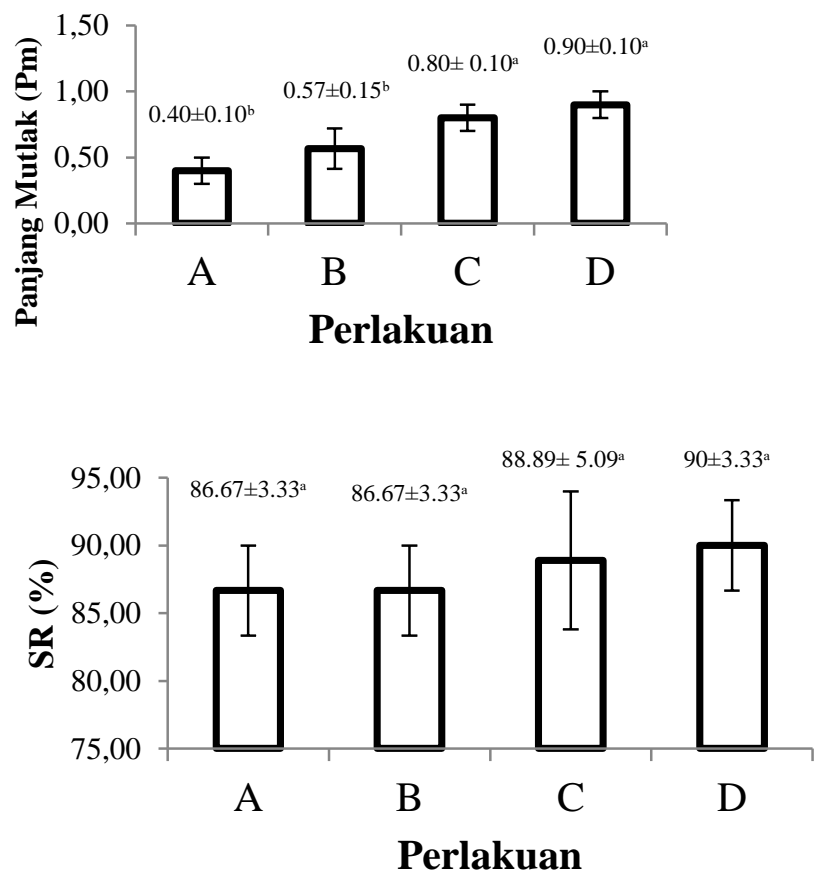
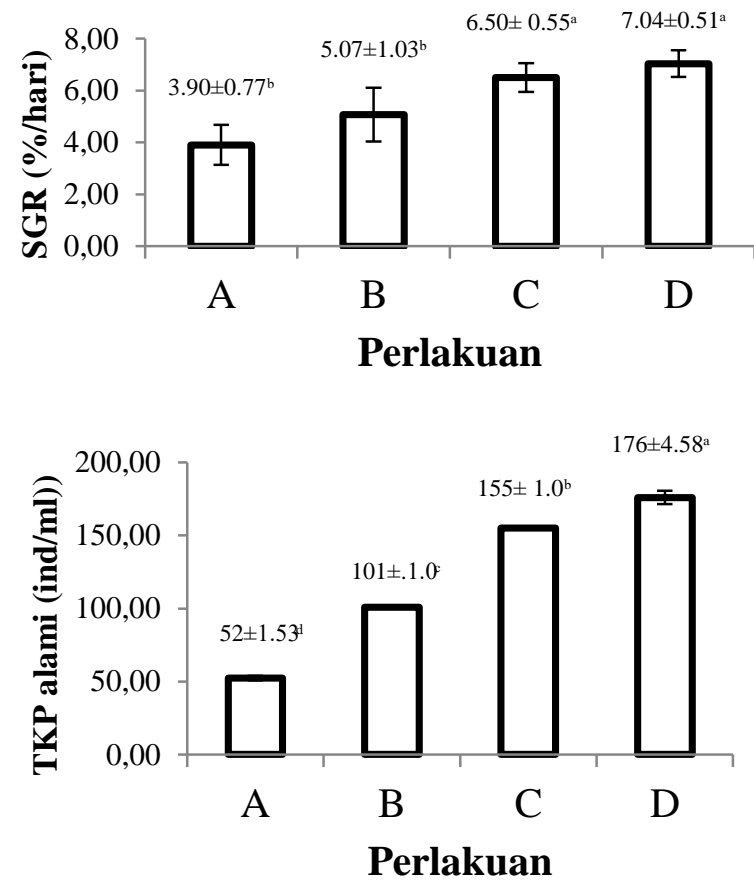

\section{b. Performa Pertumbuhan D15-D28}

Berdasarkan hasil pemeliharaan pada D16 sampai D28, diperoleh data RGR, FCR, EPP, PER, Pm dan SGR yang dapat dilihat pada Tabel 2 .

Tabel 2. Nilai Rerata TKP pakan buatan, FCR, EPP, PER dan RGR ikan baung selama penelitian

\begin{tabular}{|c|c|c|c|c|c|c|c|c|}
\hline \multirow[b]{2}{*}{ perlakuan } & \multicolumn{6}{|c|}{ Parameter } & \multirow[b]{2}{*}{$\begin{array}{l}\text { SGR } \\
(\% / \text { hari) }\end{array}$} & \multirow[b]{2}{*}{ SR } \\
\hline & $\begin{array}{l}\text { TKP } \\
(\mathrm{gr})\end{array}$ & FCR & $\mathrm{EPP}(\%)$ & $\operatorname{PER}(\%)$ & $\begin{array}{c}\text { RGR } \\
(\% / \text { hari) }\end{array}$ & $\begin{array}{l}\mathrm{Pm} \\
(\mathrm{cm})\end{array}$ & & \\
\hline $\mathrm{A}$ & $0.94 \pm 0.06^{\mathrm{c}}$ & $3.36 \pm 0.4^{b}$ & $30.14 \pm 3.8^{c}$ & $0.64 \pm 0.1^{\mathrm{c}}$ & $2.17 \pm 0.33^{\mathrm{c}}$ & $0.3 \pm 0.10^{\mathrm{c}}$ & $2.15 \pm 0.46^{b}$ & $84.60 \pm 0.6^{\mathrm{a}}$ \\
\hline B & $1.06 \pm 0.06^{\mathrm{bc}}$ & $1.83 \pm 0.4^{\mathrm{b}}$ & $57.00 \pm 14^{\mathrm{b}}$ & $1.11 \pm 0.3^{\mathrm{b}}$ & $3.80 \pm 1 .^{\mathrm{b}}$ & $0.47 \pm 0.2^{\mathrm{bc}}$ & $2.75 \pm 0.51^{\mathrm{ab}}$ & $84.65 \pm 3.5^{\mathrm{a}}$ \\
\hline $\mathrm{C}$ & $1.21 \pm 0.10^{\mathrm{a} b}$ & $1.66 \pm 0.3^{b}$ & $61.25 \pm 9^{\mathrm{a} b}$ & $1.23 \pm 0.2^{\mathrm{a} b}$ & $4.21 \pm 0.6^{\mathrm{a} b}$ & $0.60 \pm 0.1^{\mathrm{a} b}$ & $2.98 \pm 0.5^{\mathrm{ab}}$ & $85.01 \pm 3.5^{\mathrm{a}}$ \\
\hline $\mathrm{D}$ & $1.29 \pm 0.13^{\mathrm{a}}$ & $1.31 \pm 0.1^{\mathrm{a}}$ & $76.76 \pm 6.2^{\mathrm{a}}$ & $1.53 \pm 0.1^{\mathrm{a}}$ & $5.24 \pm 0.5^{\mathrm{a}}$ & $0.80 \pm 0.1^{\mathrm{a}}$ & $3.55 \pm 0.17^{\mathrm{a}}$ & $85.22 \pm 3.5^{\mathrm{a}}$ \\
\hline
\end{tabular}

\section{Keterangan :}

Nilai rerata dengan huruf superscript yang berbeda menunjukkan adanya perbedaan sangat nyata ( $\mathrm{P}<0,01)$.

Berdasarkan Tabel 2. rata-rata total konsumsi pakan (TKP) pada masing-masing perlakuan dari yang tertinggi hingga yang terendah adalah perlakuan D sebesar $1.29 \pm 0.13 \mathrm{~g}$, perlakuan $\mathrm{C}$ sebesar $1.21 \pm 0.10 \mathrm{~g}$, perlakuan B sebesar $1.06 \pm 0.06 \mathrm{~g}$, dan perlakuan A sebesar 0.94 $\pm 0.06 \mathrm{~g}$. Rata-rata nilai FCR pada masing-masing perlakuan dari yang terendah hingga yang tertinggi adalah perlakuan $\mathrm{D}$ sebesar $1.31 \pm 0.10$, perlakuan $\mathrm{C}$ sebesar $1.66 \pm 0.26$, perlakuan B sebesar 1.83 \pm 0.47 , dan perlakuan A sebesar $3.36 \pm 0.41$. Rata-rata nilai EPP pada masingmasing perlakuan dari yang tertinggi hingga yang terendah adalah perlakuan D sebesar 76.76 \pm 6.23 , perlakuan $\mathrm{C}$

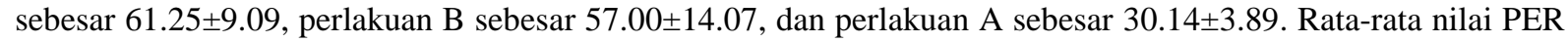
pada masing-masing perlakuan dari yang tertinggi hingga yang terendah adalah perlakuan D sebesar $1.53 \pm 0.14$, perlakuan C sebesar 1.23 \pm 0.19 , perlakuan B sebesar 1.11 \pm 0.29 , dan perlakuan A sebesar 0.64 \pm 0.10 . rata-rata nilai RGR pada masing-masing perlakuan dari yang tertinggi hingga yang terendah adalah perlakuan $D$ sebesar

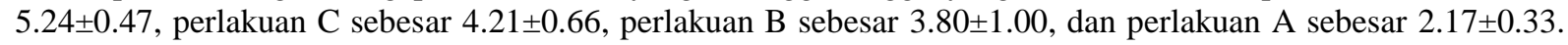
Rata-rata nilai Pm pada masing-masing perlakuan dari yang tertinggi hingga yang terendah adalah perlakuan $\mathrm{D}$ sebesar $0.80 \pm 0.10$, perlakuan C sebesar $0.60 \pm 0.10$, perlakuan B sebesar $0.47 \pm 0.15$, dan perlakuan A sebesar $0.3 \pm 0.10$. Rata-rata nilai SGR pada masing-masing perlakuan dari yang tertinggi hingga yang terendah adalah perlakuan D sebesar 3.55 \pm 0.17 , perlakuan C sebesar 2.98 \pm 0.52 , perlakuan B sebesar 2.75 \pm 0.51 , dan perlakuan A sebesar 2.15 \pm 0.46 . Rata-rata nilai SR pada masing-masing perlakuan dari yang tertinggi hingga yang terendah adalah perlakuan D sebesar 84.60 \pm 0.6 , perlakuan C sebesar 84.65 \pm 3.5 , perlakuan B sebesar 85.01 \pm 3.5 , dan perlakuan A sebesar $85.22 \pm 3.5$ 
Berdasarkan data nilai TKP, FCR, EPP, PER, RGR,Pm, SGR dan SR pada ikan baung selama pemeliharaan D15-D28 maka dapat dibuat grafik pada Gambar 2

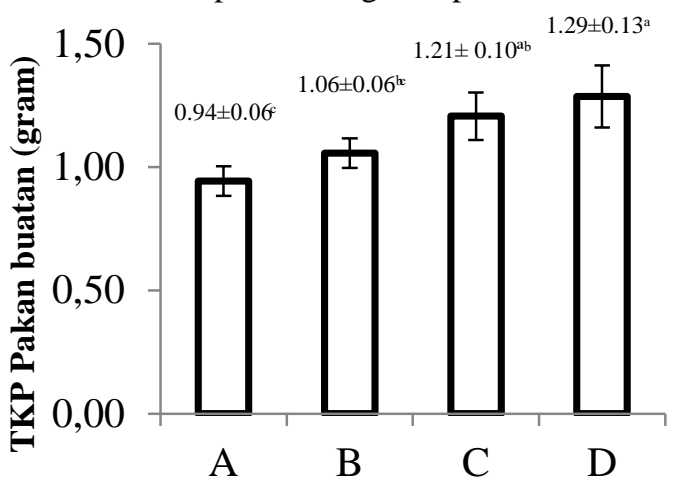

Perlakuan
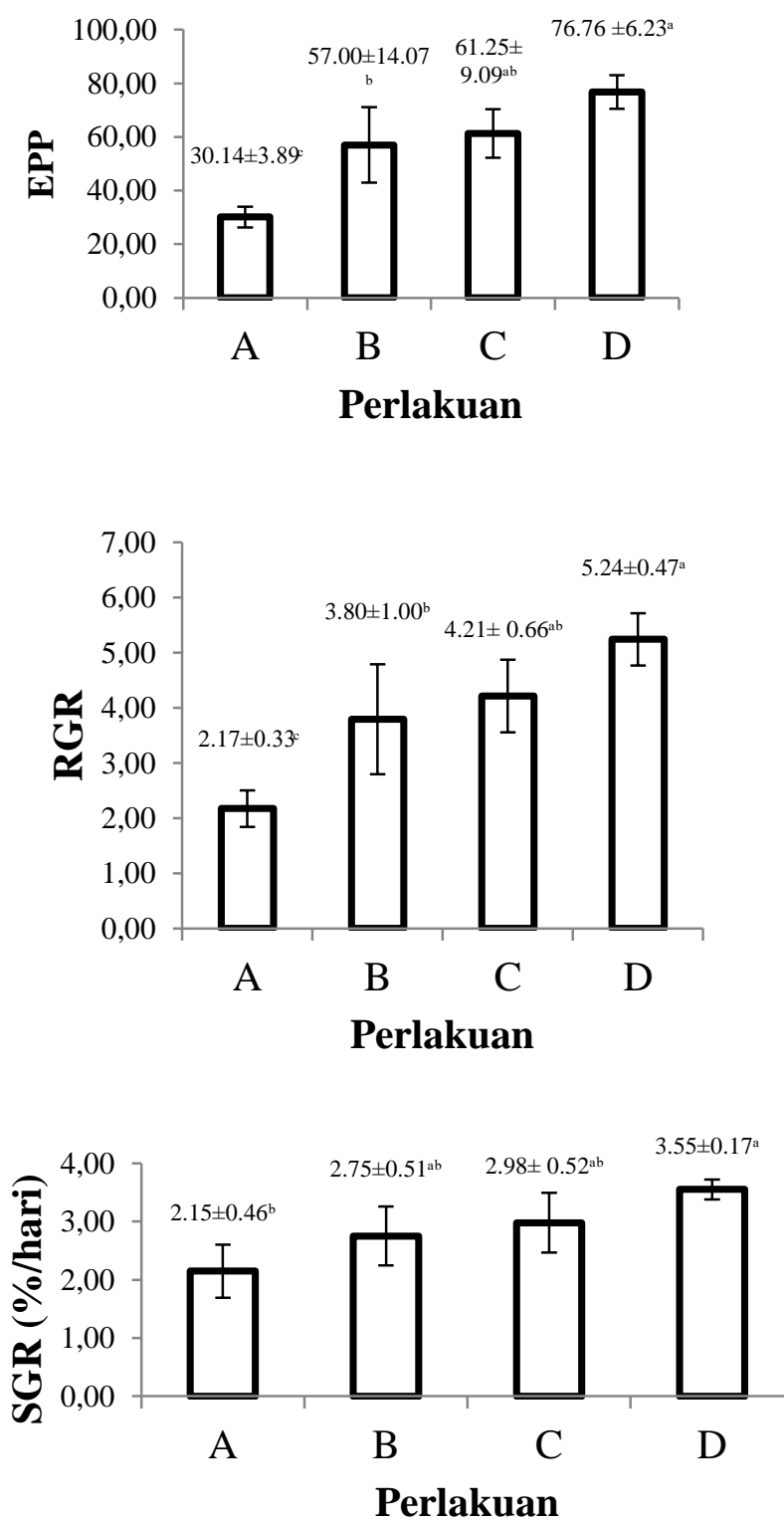
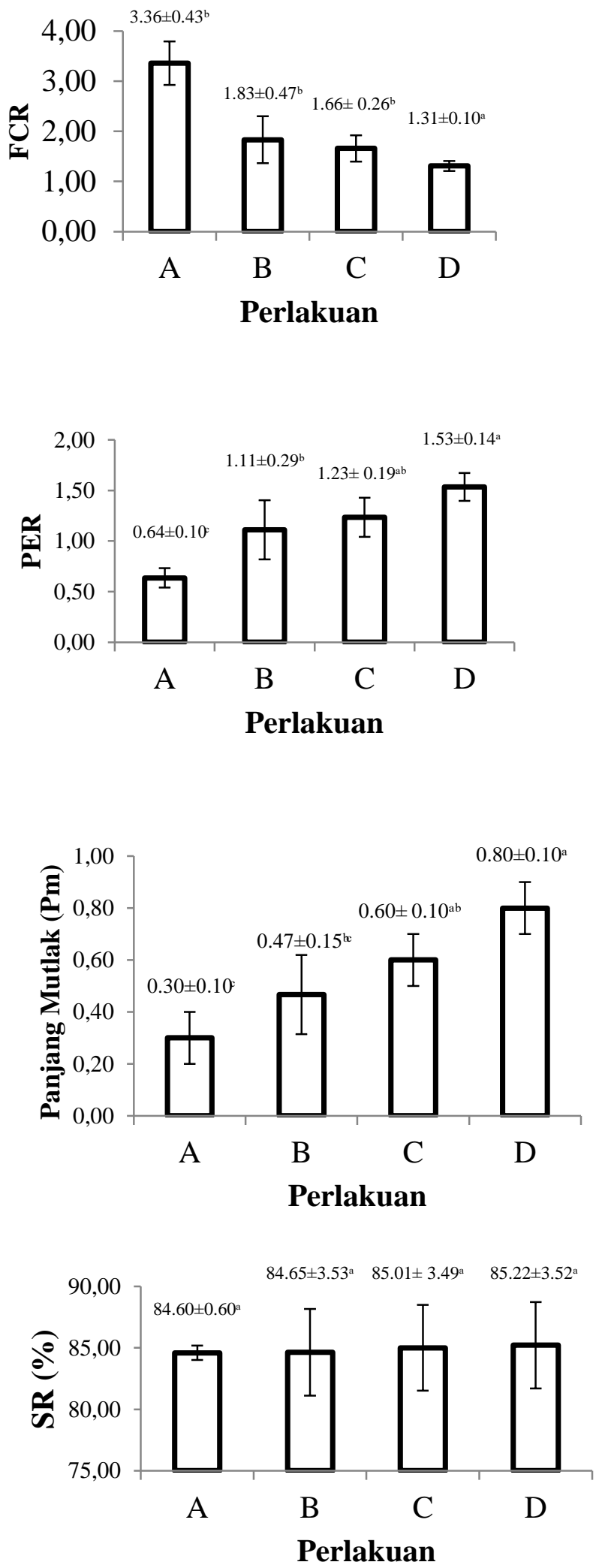


\section{Kualitas air}

Berdasarkan penelitian selama 28 hari didapatkan hasil kualitas air DO, suhu dan $\mathrm{pH}$ yang dapat dilihat pada Tabel 3.

Tabel 3. Hasil Pengukuran Kualitas Air di media larva ikan (Hemibagrus nemurus) Selama Penelitian

\begin{tabular}{|c|c|c|c|c|c|c|}
\hline \multirow{2}{*}{ Parameter } & \multirow{2}{*}{ Pukul } & \multicolumn{4}{|c|}{ Perlakuan } & \multirow{2}{*}{ Referensi } \\
\hline & & A & B & $\mathrm{C}$ & $\mathrm{D}$ & \\
\hline \multirow[t]{3}{*}{ DO } & 7.00 & $3.36-3.72$ & $3.42-3.88$ & $3.42-3.76$ & $3.42-3.83$ & \multirow{3}{*}{$* *>3 \mathrm{mg} / \mathrm{l}$} \\
\hline & 12.00 & $3.37-3.69$ & $3.38-3.73$ & $3.42-3.74$ & $3.41-3.76$ & \\
\hline & 16.00 & $3.31-3.65$ & $3.39-3.76$ & $3.42-3.85$ & $3.41-3.72$ & \\
\hline \multirow[t]{3}{*}{ Suhu } & 7.00 & $23.4-25.6$ & $23.2-25.4$ & $23-25.6$ & $23.5-25.8$ & \multirow{3}{*}{$* 25-30{ }^{\circ} \mathrm{C}$} \\
\hline & 12.00 & $23.6-25.8$ & $23.5-25.6$ & $23.5-25.8$ & $23-25.8$ & \\
\hline & 16.00 & $24-25.9$ & $23.6-25.8$ & $24-25.9$ & $23.5-25.2$ & \\
\hline \multirow[t]{3}{*}{$\mathrm{pH}$} & 7.00 & $7.4-7.76$ & $7.4-7.79$ & $7.34-7.79$ & $7.34-7.79$ & \multirow{3}{*}{$* 6,5-8,6$} \\
\hline & 12.00 & $7.38-7.64$ & $7.38-7.62$ & $7.33-7.64$ & $7.33-7.76$ & \\
\hline & 16.00 & $7.35-7.59$ & $7.35-7.59$ & $7.31-7.59$ & $7.31-7.61$ & \\
\hline
\end{tabular}

Keterangan: *SNI (2000), **Stickney (2005)

Hasil pengukuran parameter kualitas air pada media pemeliharaan ikan baung selama penelitian menunjukkan bahwa nilai kualitas air untuk DO dan $\mathrm{pH}$ masih berada berada dalam kondisi layak untuk dijadikan media budidaya.

\section{PEMBAHASAN}

\section{Performa Pertumbuhan Larva Baung}

a. D3-D15

Berdasarkan Analisis Ragam penelitian yang telah dilakukan dapat diketahui bahwa pemberian pakan alami Moina sp. dengan dosis berbeda memberikan pengaruh nyata terhadap tingkat konsumsi pakan alami. Hal tersebut diduga karena pakan alami Moina sp sangat cocok dan juga menarik perhatian ikan baung untuk memangsanya. Sehingga semakin banyak dosis yang diberikan kepada ikan baung maka semakin tinggi pula konsumsi pakan alami nya. Menurut Lolita (2006) Moina sp. sebagai pakan ikan memiliki keunggulan antara lain ukuran Moina sp sangat cocok untuk bukaan mulut larva ikan serta sifatnya yang bergerak aktif akan menarik benih untuk memangsa Moina sp. Sehingga dapat diduga bahwa hal tersebut yang memacu larva ikan baung untuk mengkonsumsi Moina sp.

Moina sp. merupakan pakan alami yang memiliki kandungan gizi berupa protein 37,38 \%, lemak 13,29 $\%$, serat kasar 0,00\%, abu 11,00\%, dan kadar air sebesar 99,60\%. Dengan kandungan tersebut diduga apabila Moina sp. dikonsumsi dengan jumlah yang banyak dan cukup maka semakin banyak pula kandungan nutrisi dari Moina sp yang dapat diserap oleh tubuh larva baung dan dimanfaatkan untuk pertumbuhan. Protein merupakan sumber energi utama untuk menunjang pertumbuhan ikan. Menurut Anggraeni dan Nurulita (2013) ikan akan memanfaatkan nutrien pakan untuk disimpan dalam tubuh dan mengkonversinya menjadi energi. Energi ini digunakan oleh ikan untuk metabolisme dasar, pergerakan, produksi organ seksual, perawatan bagian-bagian tubuh serta pergantian sel-sel yang telah rusak dan kelebihannya digunakan untuk pertumbuhan. Diduga dengan pemberian pakan alami Moina sp. dosis $20 \mathrm{ind} / \mathrm{ml}$ memberikan energi lebih tinggi dari perlakuan lain yang membuat larva mendapatkan energi lebih tinggi yang digunakan untuk pertumbuhannya.

Tingkat konsumsi pakan alami tertinggi di dapat pada perlakuan D yaitu dengan kepadatan $20 \mathrm{ind} / \mathrm{ml}$. hal tersebut diduga karena perlakuan D merupakan dosis tertinggi bila dibanding dengan perlakuan A, B dan C yang membuat larva ikan baung lebih banyak mengkonsumsi pakan alami di perlakuan D. Pada perlakuan D larva baung tidak menghabiskan pakan alami sebanyak $20 \mathrm{ind} / \mathrm{ml}$ dan masih ada sisa di wadah pemeliharaan setiap harinya, diduga hal tersebut karena pada dosis di bawah $20 \mathrm{ind} / \mathrm{ml}$ larva baung sudah merasa kenyang. Hal tersebut diperkuat oleh Rahmawati dan hayuningtyas (2014) bahwa kekenyalan lambung akan memonitor tingkat kepenuhan lambung pada ikan dan selanjutnya menginformasikan tentang ruang yang tersedia dalam lambung untuk kegiatan makan berikutnya ke pusat makan di hipotalamus

Ikan Baung merupakan salah satu ikan endemik yang sangat peka terhadap perubahan lingkungan, sehingga dalam budidaya ikan baung, faktor lingkungan juga sangat perlu diperhatikan. Pakan alami adalah suatu organisme hidup yang diberikan kepada kultivan sebagai sumber pakan awal larva. Jumlah pakan alami yang terlalu banyak akan menyebabkan penurunan kualitas air dan apabila terlalu sedikit akan menyebabkan kekurangan nutrisi bagi ikan baung,sehingga dalam pemberian pakan alami perlu di perhatikan dosis pemberiannya. Menurut Noventalia et al (2012), kelimpahan zooplankton pada suatu perairan dapat 
menggambarkan jumlah ketersediaan makanan, maupun kapasitas lingkungan/ daya dukung lingkungan yang dapat menunjang kehidupan biota. Dengan demikian, perubahan kelimpahan biota zooplankton dapat digunakan untuk mengetahui perubahan yang terjadi pada suatu wilayah perairan.

Berdasarkan analisa Ragam pada penelitian ini diketahui bahwa pemberian pakan alami Moina sp. dengan dosis $20 \mathrm{ind} / \mathrm{ml}$ memberikan hasil pertumbuhan panjang mutlak dan laju pertumbuhan spesifik terbaik dibanding perlakuan A, B dan C Hal tersebut diduga karena jumlah pakan yang diberikan pada tiap perlakuan sangat mempengaruhi pertumbuhan panjang larva baung Menurut Chotimah et al (2017), kecepatan pertumbuhan ikan tergantung pada jumlah pakan yang diberikan, ruang, suhu, kedalaman air dan faktor-faktor lain. Sehingga diduga jumlah pakan yang dikonsumsi antar perlakuan menyebabkan pertumbuhan panjang larva berbeda nyata.

\section{b. D15-D28}

Pemberian pakan alami dengan dosis yang berbeda juga memberikan pengaruh nyata terhadap tingkat konsumsi pakan buatan, Hal tersebut diduga karena pada fase D15-D28 pemberian pakan buatan menggunakan cara fix feeding rate 5\% dari bobot biomassa, sehingga larva hasil pemberian pakan alami dengan dosis yang berbeda dengan bobot tertinggi juga akan mendapatkan pakan buatan terbanyak. Hal tersebut juga diperkuat oleh Tipayadara et al, 2016 bahwa faktor-faktor lain juga mempengaruhi tingkat pemberian makan pada kultur ikan, misalnya, ukuran ikan, spesies dan sistem pemeliharaan.

Berdasarkan penelitian yang telah dilakukan dapat diketahui bahwa pemberian pakan alami Moina sp dengan jumlah yang berbeda pada D3-D15 juga memberikan pengaruh sangat nyata terhadap nilai Food Convertion Rate (FCR), Efisiensi pemanfaatan pakan (EPP), ratio efisiensi protein (PER) dan laju pertumbuhan relative (RGR) larva ikan baung. Nilai terbaik FCR, EPP, PER dan RGR didapatkan pada perlakuan D yaitu FCR

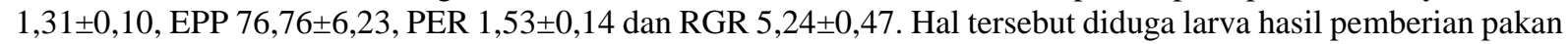
alami dosis $20 \mathrm{ind} / \mathrm{ml}$ memberikan hasil terbaik dalam perkembangan organ pencernaan sehingga ketika D15-D28 pakan buatan yang diberikan akan lebih cepat dicerna bila dibanding dengan perlakuan A,B dan C. Menurut Effendi et al (2003), Pada larva ikan, alat pencernaannya masih sangat sederhana, relatif pendek, dan belum berdiferensiasi, kemudian dengan bertambahnya umur melalui diferensiasi alat pencernaan, larva ikan akan berubah perlahan-lahan memasuki stadia dengan habitat pemangsaan yang spesifik. Perkembangan tersebut selain terjadi secara morfologis/anatomis, juga secara fisiologis yakni perkembangan enzim-enzim pencernaan dan aktivitasnya, sehingga struktur morfologis saluran pencernaan yang masih sederhana berkorelasi dengan rendahnya produksi enzim-enzim pencernaan dan ini merupakan masalah utama dalam pemberian pakan bagi larva pada stadia awal.

Pakan bisa mempengaruhi metamorfosis, perkembangan awal dan viabilitas larva sehingga diduga pakan alami dengan jumlah yang mencukupi akan membantu mempercepat perkembangan organ pencernaan larva, dalam penelitian Srichanun et al (2011) dikatakan bahwa Enzim eksogen dari pakan hidup memainkan peranan penting peran dalam membantu proses pencernaan pada larva ikan maupun udang. Moina sp. membantu proses pencernaan larva melalui kontribusi aktivitas tripsin, chymotrypsin dan amylase.

Pertumbuhan panjang mutlak dan laju pertumbuhan spesifik larva baung pada fase D3-D15 menunjukan nilai yang lebih tinggi yaitu pertumbuhan panjang mutlak perlakuan D sebesar $0,90 \pm 0,10$ dan SGR sebesar $7,04 \pm 0.51$ dibanding pada fase D15-D28 pertumbuhan panjang mutlak pada perlakuan D yaitu $0,80 \pm 0,1$ dan SGR 3,55 $\pm 0,17$ Bobot awal dalam penentuan jumlah pakan buatan sangat dipengaruhi oleh biomassa pada D15 atau akhir pemberian pakan alami sehingga ketika perpindahan ke pakan buatan jumlah pakan buatan mengikuti dari bobot biomassa pada D15. Menurut Tippayadara et al, (2016) Feeding rate memiliki peran yang signifikan terhadap kinerja pertumbuhan, konversi pakan, efisiensi retensi nutrisi dan komposisi kimia pada ikan. Faktorfaktor lain juga mempengaruhi tingkat pemberian makan pada kultur ikan, misalnya, ukuran ikan, spesies dan sistem pemeliharaan, ketika bobot hidup individu ikan meningkat, persentase penggunaan pakan menurun. Tingkat pemberian pakan yang optimal relatif membantu dalam meminimalkan jumlah pemberian pakan, mengurangi pencemaran air dan penurunan investasi modal dalam produksi akuakultur.

\section{Kelulushidupan larva baung}

Berdasarkan hasil analisa ragam yang telah dilakukan dapat diketahui bahwa kelulushidupan larva ikan baung dengan permberian pakan alami Moina sp denggan dosis yang berbeda tidak berpengaruh nyata baik pada periode D3-D15 ataupun D15-D28. Hal tersebut diduga karena pakan alami tidak berpengaruh langsung dalam kelulushidupan larva ikan baung. Kelulushidupan Larva dapat dipengaruhi oleh beberapa faktor diantaranya seperti yang telah dikatakan Mulyani et al (2014), bahwa kelangsungan hidup ikan dipengaruhi oleh faktor internal dan eksternal. Faktor internal berasal dari ikan itu sendiri. Ikan mengalami stress karena perlakuan yang kurang hati-hati sehingga mortalitasnya tinggi dan adanya persaingan makanan. Faktor eksternal yang berpengaruh antara lain kondisi lingkungan seperti, kondisi tempat yang kurang mendukung dalam pemeliharaan.

Kualitas air dalam penelitian ini berada dalam kisaran yang optimal untuk DO dan $\mathrm{pH}$ nya yaitu pada perlakuan $\mathrm{A}, \mathrm{B}, \mathrm{C}$ dan $\mathrm{D}$ berada pada kisaran $>3 \mathrm{mg} / \mathrm{L}$ dan $\mathrm{pH}$ 7-8 namun suhu terkadang masih berfluktuasi sangat dingin karena sempat berada pada nilai $23^{\circ} \mathrm{C}$. suhu yang dingin dapat menimbulkan ikan sulit untuk bertahan hidup dan terjadi kematian seperti yang telah dikatakan oleh Yanuar (2017) bahwa Suhu adalah salah satu parameter penting dalam budidaya perikanan. Jika suhu lebih rendah dari suhu optimal, maka ikan akan kehilangan 
nafsu makan dan rentan terhadap penyakit. Sebaliknya jika suhu lebih tinggi dari $42{ }^{\circ} \mathrm{C}$, ikan akan mengalami stress bahkan menyebabkan kematian.

Kelulushidupan terbaik pada D3-D15 didapat pada perlakuan D yaitu sebesar $90,00 \pm 3,33 \%$ dan pada D15-D28 kelulushidupan tertinggi juga terdapat pada perlakuan D yaitu $85,22 \pm 3.5 \%$. Hal tersebut diduga karena pakan alami yang diberikan pada tiap perlakuan dosis nya berbeda sehingga tingkat kelangsungan hidup larva yang diberi pakan lebih banyak memiliki kelulushidupan yang tinggi pula.karena energi yang didapat dari pakan dapat digunakan untuk sistem imunnya. Menurut Muchlisin et al. (2003) untuk mendapatkan kelangsungan hidup yang baik diperlukan pemberian pakan yang tepat baik ukuran, jumlah, dan kandungan gizinya. Sehingga dengan pemberian dosis Moina sp tertinggi juga memberikan tingkat kelulushidupan yang baik.

Berdasarkan hasil yang telah didapat dari penelitian dapat diketahui bahwa pola pertumbuhan dan kelulushidupan larva ikan baung dari D3-D15 brbanding lurus dengan pola pertumbuhan dan kelulushidupan larva ikan baung pada D15-D28. Dalam Feeding regime pada D3-D15 larva ikan baung mengkonsumsi pakan alami dengan perlakuan yang berbeda. Hal tersebut yang menyebabkan larva ikan baung memiliki perbedaan pada setiap variable, pada perlakuan D laju pertumbuhan spesifiknya lebih tinggi sehingga pertumbuhan panjang mutlaknya pun sebanding, dan untuk kelulushiduan nya pun sebanding karena perlakuan D memberikan nilai SR yang lebih tinggi bila dibanding dengan perlakuan lainnya hal tersebut dikarenakan asupan pakan pada perlakuan D memberikan energy lebih yang dapat dimanfaatkan untuk pertumbuhan dan juga kelulushidupan. Menurut Anggraeni dan Nurulita (2013) ikan akan memanfaatkan nutrien pakan untuk disimpan dalam tubuh dan mengkonversinya menjadi energi. Energi ini digunakan oleh ikan untuk metabolisme dasar, pergerakan, produksi organ seksual, perawatan bagian-bagian tubuh serta pergantian sel-sel yang telah rusak dan kelebihannya digunakan untuk pertumbuhan.

Perlakuan pada D3-D15 juga berdampak kepada performa pertumbuhan dan kelulushidupan larva pada D15-D28. Hal tersebut diduga karena larva hasil pemberian Moina sp dengan dosis yang berbeda juga mempengaruhi proses perkembangan organ pencernaan, sehingga mempengaruhi dari performa pertumbuhan seprtiyang telah dikatakan oleh effendi (2003) bahwa seiring bertambahnya umur melalui diferensiasi alat pencernaan, larva ikan akan berubah perlahan memasuki stadia habitat pemangsaan yang spesifik.

\section{KESIMPULAN DAN SARAN \\ Kesimpulan}

Kesimpulan yang didapat dari penelitian pengaruh pemberian pakan alami Moina sp dengan dosis yang berbeda terhadap pertumbuhan dan kelulushidupan larva ikan baung adalah :

1. Terdapat perbedaan sangat nyata $(\mathrm{P}<0.01)$ terhadap TKP alami, pertumbuhan panjang mutlak, dan SGR pada D3-D15 serta pada D15-D28 juga terdapat perbedaan nyata $(\mathrm{P}<0.01)$ terhadap TKP buatan, pertumbuhan panjang mutlak, SGR, FCR, EPP, PER, RGR namun tidak memberi pengaruh nyata $(\mathrm{P}>0.05)$ terhadap kelulushidupan larva ikan baung.pada D3-D15 dan D15-D28.

2. Perlakuan D memberikan nilai terbaik terhadap performa pertumbuhan larva baung pada D3-D15 dengan nilai pertumbuhan panjang mutlak $0.9 \pm 0.10$, SGR 7,04 $\pm 0,51$, SR $90 \pm 3,33$ dan pada D15-D28 panjang mutlak $0,8 \pm 0,10$, SGR $3,55 \pm 0,17$, FCR 1,31 $\pm 0,1$, EPP 76,76 $\pm 6,2$, PER 1,53 \pm 0.1 , RGR 5,24 $\pm 0,5$, SR $85,22 \pm 3,5$.

\section{Saran}

Saran yang dapat diberikan dari penelitian pengaruh pemberian pakan alami Moina sp dengan dosis yang berbeda terhadap pertumbuhan dan kelulushidupan larva ikan baung adalah :

1. Perlu penggunaan dosis Moina sp sebanyak 20 ind/ml sehingga larva ikan baung umur D3-D28 mencapai pertumbuhan dan kelulushidupan terbaik.

2. Sebaiknya dalam pemeliharaan larva ikan baung suhu media di atur agar tidak terlalu rendah ataupun terlalu tinggi.

\section{UCAPAN TERIMA KASIH}

Terima kasih penulis ucapkan kepada Bapak Fidil Rahmat S.Pi, selaku Kepala Unit Pelaksana Teknis Balai Benih Ikan (UPT BBI) Sawangan, Kabupaten Magelang yang telah memberikan fasilitas selama penelitian. 


\section{DAFTAR PUSTAKA}

Anggraeni, N. M dan Nurulita A. 2013. Pengaruh Pemberian Pakan Alami dan Pakan Buatan Terhadap Pertumbuhan Ikan Betutu (Oxyeleotris marmorata) pada Skala Laboratorium. Jurnal Sains dan Seni Pomits Vol. 2, No.1, (2013) 2337-3520

Chotimah. S., Rusliadi dan U. M. Tang.2017. Pertumbuhan Dan Kelangsunganhidup Ikan Baung (Mystus Nemurus C.V) dengan Padat Tebar Berbeda pada Sistem Resirkulasi.[skripsi]. 106 hlm

Effendi, H. 2003. Telaah kualitas air. Kanisius. Yogyakarta.

Hung. L. T., Tuan. N. A., P. Cacot, J. Lazard. 2002. Larval Rearing Of The Asian Catfish, Pangasius Bocourti (Siluroidei, Pangasiidae): Alternative Feeds And Weaning Time. J. Aquaculture 212:115-127

Huwoyono, G. H ., Suhenda. N dan A. Nugraha.2011. Pembesaran Ikan Baung (Hemibagrus Nemurus) yang Diberi Pakan Berbeda Dikolam Tanah [Grow Out Of Green Catfish (Hemibagrus Nemurus) By Using Different Feed Types In The Earthern Pond]. Berita Biologi 10(4): 557-562

Lolita. T.N. 2006. Pembudidayaan ikan. BRKP, Jakarta: 62 hlm.

Muchlisin, Z.A. 2003. Preliminary Study on a Spermatozoa Cryopreservation and Effect of Dietary Protein on Gonadal Development of Bagrid Catfish Mystus Nemurus Broodstock. Thesis. Scholl Of Biological Sciences, University Sains Malaysia, Penang.

Muflikhah N, Nurdawati. S dan S. N. Aida. 2006. Prospek Pengembangan Plasma Nutfah Ikan Baung (Mystus nemurus C.V.). BAWAL. 1 (1) : 11-17.

Mulyani, Y., S. Yulisman., dan M. Fitrani. 2014. Pertumbuhan Dan Efisiensi Pakan Ikan Nila (O.niloticus) Yang Dipuasakan Secara Periodik. Jurnal Akuakultur Rawa Indonesia. 02(01): 01-12

Noventalia, I., Endrawati, H., M. Zainuri. 2012. Struktur Komunitas Zooplankton Di Perairan Morosari, Kecamatan Sayung, Kabupaten Demak. Journal of Marine Researc. 1(1): 19-23

Rahmah. S, Kato. K1, S. Yamamoto1, K. Takii2, O. Murata1 dan S. Senoo. 2014. Improved Survival and Growth Performances with Photoperiod and Feeding Schedule Manipulation in Bagrid Catfish Mystus nemurus (Cuvier \& Valenciennes 1840) larvae.J. Aquaculture Research,. 45: 501-508

Rahmawati. R, K.Eni,dan E.P. Hayuningtyas. 2014. Pertumbuhan dan Tingkat Konsumsi pakan Tubifex sp pada ukuran Ikan Cupang (Betta imbelis) yang berbeda. Prosiding forum Inovasi Teknologi Akuakultur

Rottmann, R.W., J.S. Graves., C. Watson \& R.P.E. Yanong. 2003. Culture techniques of Moina: The ideal Daphnia for feeding freshwater fish fry. University of Florida, Florida: 1-6 hlm

SNI. 2000. Standar benih ikan lele dumbo (Clarias gariepinus) kelas benih sebar. Badan Standarisasi Nasional. SNI 01- 6484.2 -2000.

Srichanun,M.,Tantikitti., V. Vatanakuf., P. Musikarune. 2012. Digestive enzyme activity during ontogenetic development and effect of live feed in green catfish larvae (Mystus nemurus Cuv. \& Val.). J.sci.technologi. 34 (3):247-254

Stickney, R.R., 2005. Aquaculture: An introductory text. CABI Publishing. USA.256p.

Tippayadara. N.,Doolgindachbaporn. S dan A. Suksri. 2016. Effects of Feeding rates on Growth Performance, Feed Utilization and Body Composition of Asian Red Tail Catfish (Hemibagrus wyckioides), Cultured in Northeast Thailand. Pakistan Journal of Biological Sciences. 19 (2): 57-64.

Yanuar, V. 2017. Pengaruh Pemberian Jenis Pakan yang Berbeda Terhadap Laju Pertumbuhan Benih Ikan Nila (Oreochromis niloticus) dan Kualitas Air di Akuarium Pemeliharaan. Ziraa'ah 42(2): 91-99

Yustina, A 2003.Daya Tetas dan Laju Pertumbuhan larva Ikan Hias Beta Spendens Di Habitat Buatan. jurnal biologi. PMIPA, FKIP, universitas riau. 5 (2) : 129-123. 